\title{
In Fulfillment of Motherhood: An Exploratory Study of Migrant Mothers on Welfare in Japan
}

\author{
Jocelyn O. Celero
}

Published online: 1 July 2014

(C) Springer International Publishing 2014

\begin{abstract}
The paper primarily aims to (1) highlight the profile, perceptions, and politics of using seikatsu hogo (living subsidy allowance) of Filipino migrant mothers whose everincreasing participation in the labor sector and society has inevitably shaped the public's expectations on family-related and welfare policies of Japan, (2) locate, through their subjective experiences as consumers, the impact of seikatsu hogo on their lives as non-citizens who are currently reconfiguring the Japanese family and society. This study utilizes life vignettes obtained from in-depth interviews with (30) Filipino mothers residing and leading their family in Tokyo. It also illustrates that Filipino migrant mothers are, in the existing dual welfare hierarchies vis-à-vis Japanese and other migrants, occupants of the lowest tier. Beyond dichotomization between Japanese and non-Japanese poor, Filipino mothers are further fragmented in terms of how welfare support reconfigures family life. While some regard it as a status determinant, others claim it as a resource for socioeconomic empowerment. Their politics of welfare use intersects with the politics of family relations in which Filipino mothers value parenthood over marriage. Family relations reinforce family solidarity through migrant mothers" "best mother" and "model adult citizen" aspirations. As Japan grapples with exacerbating demographic problems and economic stagnation, it may have to reconsider facilitating migration and view immigrant women as potential source of labor force. However, in making women, citizens, and non-citizens, more visible in the labor market, welfare policies should vigorously work toward allowing them to balance work and family life by having greater access to childcare.
\end{abstract}

J. O. Celero $(\bowtie)$

Waseda University, Tokyo, Japan

e-mail: joyous_ph@yahoo.com
Keywords Seikatsu hogo · Filipino migrant mother · Japan · Best mother · Model adult citizen · Politics of welfare use

\section{Introduction}

Migrants on Welfare and the Future of Japan

Reaching above two million (MOJ, 2012), the migrant population has contributed to Japan's crucial task of developing well-defined policies to promote immigrants' rights, welfare, protection, and gradual integration to its mainstream society. Japan's lack of response to this crucial task has indicated the nation state's inability to determine the future destiny of its immigrant settlers. Tsuda (2006, p. 5) elucidates that the state's negligence to provide citizenship rights is mainly due to the state's view of immigrants as illegitimate and short-term residents. Despite this dubious expectation, Japan boasts of its quite comprehensive set of allowances and services that characterizes its welfare-to-work regime (Ewaza 2005, p. 54) which has catered to the needs of groups of citizens and allowed certain members of the migrant populace to partake.

One of the social policies Japan designed to extend support for families is the public assistance program, otherwise known as seikatsu hogo. It is a welfare benefit system that provides necessary assistance to all people who are unable to meet the minimum standards of living (Aoki and Aoki 2005, p. 18; italics for emphasis) by virtue of the 1950 Livelihood Protection Act that upheld the people's right to a fairly decent life which had been promoted by those political leaders who were pro-livelihood protection at the time (Japanese Law Translation 2009; also cited in Soeda, 1990, p.10). Aimed at maintaining minimum standards of living and achieving socio-economic freedom, seikatsu hogo is hitherto paid for by the municipal government based on eight categories as follows: basic living expenses that cover food, clothing, and 
Fig. 1 Welfare recipients, 1950 2010 (source: Ministry of Health, Labor and Welfare)

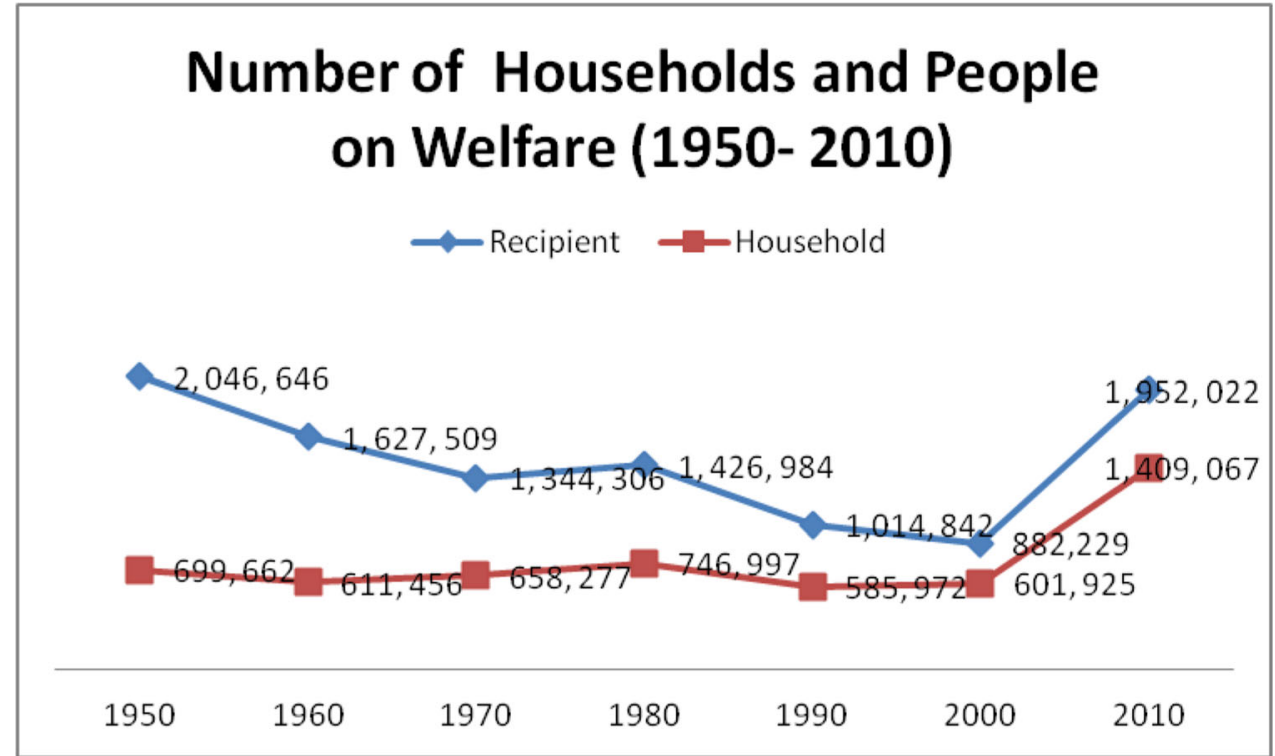

utilities; housing costs; compulsory education; medical care; elderly care; cost for giving birth; skill training; and funerals (Public Assistance System, n.d.).

Determining those who are eligible for public assistance is through means test standard, which implies that potential recipients must bear the burden of proving their eligibility, thus resulting to their stigmatization as stricken individuals as well as weakened public support for the said policy (Adolino and Blake 2001, p. 247). Nevertheless, recipients of the living subsidy allowance must fulfill their obligations commensurate to the benefits they receive by leading a decent and independent life and utilizing her/his resources as well as the other family members, including savings, real estate, valuable objects as well as their ability to work (Solidarity Network with Migrants-Japan, n.d.). In other words, seikatsu hogo is the government's effort to narrow living disparities among citizens for them to attain as much as possible socio-economic equality (Fig. 1).

While the living subsidy programs are made accessible solely to all Japanese citizens in accordance with the public assistance law, migrants have also been covered by this welfare program, following the humanitarian decision of local governments in 1954 to give out support to needy foreign residents, which include "special permanent and permanent residents, spouses of permanent foreign residents or Japanese nationals, and those who received refugee status from the government" (Kamiya 2011). The data released by the Ministry of Health, Labor and Welfare showed that as of fiscal 2009 , more than 444,000 households with foreign nationals or 731,000 foreigners, received public assistance. In 2011, the number of households receiving welfare reached as high as 1.4 million, while the number of individuals in need of welfare went an all-time high of 2. 06 million (Ministry of Health, Labor and Welfare, 2011; also cited in Kamiya 2011).
Needless to say, migrants have added to the growing importance of welfare subsidies that the government has provided for as much as their rapidly increasing number has inevitably formed an integral part of the transformation of Japan's social, cultural, and economic structures. These intertwined realities spell out considerable implications not only on welfare consumption and spending but also largely on the future of Japan's welfare state.

Among these structures, the family is regarded as the cornerstone of Japanese society (Takahashi 2010, p. 56) and crucial site for welfare policies mainly, in this paper, seikatsu hogo. Peng (cited in Ito Aspalter, 2002, pp. 41-42) notes that the family, as well as the corporate sector, has always been the focus of Japan's welfare system. The exacerbating demographic and economic concerns have led to welfare state restructuring in Japan beginning the 1990s which have affected the politics of gender relations in which women as well as migrants constituted the so-called marginalized groups (Peng as cited in Alster, 2002). With migrants being frequently identified, along with Japanese women, as minority groups in relation to welfare has led to their very limited to almost non-visibility in literature on Japan's welfare state, as if their conditions and perceptions on welfare are synonymous to those of Japanese women. In relation to welfare consumption, immigrants have been depicted as one of the, in Clarke's term (2004, p. 33), "social problem groups," although they remain understudied.

Several studies on welfare in Japan focused on more specific groups of Japanese: (1) single mothers (Iwata 2007; Ezawa 2005, p. 2); (2) those who are often unmarried, low-skilled, part timer, or low-paid (Wright 2001); and (3) the youth and the elderly who are regarded as the population at social risk (Estevez-Abe, 2009). While most existing studies on welfare have been highly quantitative, 
drawing on demographic or mass surveys which often lack analysis of the relationship between women's lives and wider society (Wright 2001), the current study takes a more qualitative approach to exploring mothers and their children's "chain of disadvantages" (Aoki and Aoki 2005, p. 3 ), those economic, social and cultural limitations surrounding welfare consumption.

This research highlights the profile, perceptions, and politics of welfare use of, specifically, Filipino migrant mothers in Japan. Although migrants constitute a vulnerable group on welfare, their growing presence in the labor sector and Japanese society matter as they too, to a certain degree, shape the public's expectations on family policy. While they are yet to gain visibility and voice in policymaking, migrants' perspectives on welfare use would give a valid basis for assessing the impact of seikatsu hogo into their lives as non-citizens and members of reconfiguring Japanese family and society. Moreover, locating Filipino migrant mothers' views and attitudes toward seikatsu hogo sets an important guide to explore the ways in which they articulate the politics of family relations. As Daly (2004, p. 151) justifies, the recent developments around the family cast an interesting light on welfare state reform. The evolving structure of family challenges states to carry out new duties which enable these states to create diverse family support policies amidst the growing trend toward policy retrenchment.

This study gathers the perceptions of Filipino mothers on migrants' use of the living subsidy system or seikatsu hogo in Japan. The paper aims to structure and link those views to migrants' politics of family relations. This attempts to shed light on the following research questions:

1. Who are Filipino women on welfare? Do they form a diverse or distinct group?

2. How do they view seikatsu hogo and themselves as its recipients?

3. How are these perceptions linked to their views on family relations?

To fulfill the aims of this paper, the discussion is divided into three parts: (1) profile of Filipino migrant mothers on welfare; (2) their views on seikatsu hogo which are then interconnected to; (3) the politics of family relations.

\section{Theoretical Framework}

The Politics of Welfare Use and Family Relations

People actively construct their own realities from the symbols around them through social interaction (Blumer 1969). Describing the phenomenon of welfare use through the accounts or narratives of welfare users on seikatsu hogo provides a more nuanced understanding of who those migrants on welfare are and how and why migrants choose to be on it. It is hypothesized that migrants, compared to citizen dependents, are not easily "magnetized" by welfare benefits, and their politics of welfare use often intersect with the politics of family relations. This particular issue has pervasively surfaced in the life narratives of Filipino migrant mothers in this study.

Family relations, according to Giddens (cited in Daly 2004, p. 144), must embody principles of "equality, mutual respect, autonomy, decision-making through communication, and freedom from violence." To analyze the politics of family relations, this study referred to Daly's (2004) depiction of family transformation through the shifting meanings of family obligations and family solidarity. Family obligations, she observed, have been redefined in the contemporary social policies in such a way that these have become concentrated on parenting responsibilities instead of spousal solidarity. Family solidarity, on the other hand, is an offshoot of the reconfiguration of family obligations, evident in parents' capacity to discern their responsibilities and determination to uphold them. Thus, women aspire to become the "best mother" through combining motherhood and employment (EspingAndersen Gosta 2000, also cited in Jenson 2009, p. 465) and "model adult citizen" through supporting herself in the labor market instead of depending on the state for support (Lister 2004, p. 174).

To sum it up, this study critically examines how Filipino migrant mothers on seikatsu hogo articulate their politics of welfare use in relation to managing family relations by locating elements of family obligations and family solidarity.

\section{Research Method}

This qualitative study was based mainly on fieldwork research conducted beginning 2010 to 2012 and formed part of the researcher's larger study on Filipino mother families' socioeconomic integration to Japanese society. Data was derived from in-depth interviews with (30) Filipino migrant mothers currently residing in Tokyo, which is one of the major cities where most Filipino migrants reside. ${ }^{1}$ Snowball technique was employed to locate participants who were willing to participate in this research and, at the time of interview, were seikatsu hogo beneficiaries.

Semi-structured interviews were conducted in a mix of Japanese, English, and Filipino to elicit demographic data (age, education, length of residence in Japan, type of housing, economic background, family size, etc.) as well as life narratives with emphasis on their experiences of utilizing seikatsu

\footnotetext{
${ }^{1}$ As of 2012 , there are 898,794 or $39 \%$ out of the $2,317,856$ foreign nationals residing in Tokyo, Kanagawa, Chiba, and Saitama. (Source: Ministry of Internal Affairs and Communication)
} 
hogo while raising a family in Japan. Interviews were fully transcribed and translated into English before coding their experiences based on the following issue areas: (1) reasons for applying for seikatsu hogo, (2) sources of information, (3) processes of application, (4) family life changes upon receiving benefits and, (5) personal and family life goals. These key issues on welfare utility were identified as salient points for illustrating the linkage between welfare use and family relations.

For purposes of exploring diverse sets of ideas for constructing the identity of a Filipino migrant mother on welfare as well as the social realities embedded in the practice of welfare consumption, subjective experiences of selected respondents were analyzed. Rather than to create a representative sample, these narratives presented herein have more or less captured various experiences shared not only by Filipino women but also, presumably, by other migrants on welfare in Japan. To analyze, the subjectivity of welfare practice among immigrant mothers qualitatively entailed interpretation of the meanings behind the practice beyond depiction of the practice itself. This study therefore employed textual analysis of transcribed narratives in order to elicit values of welfare use and how such values shape family relations, employing theoretical tools, namely family obligations and family solidarity. Through conceptual coding, the former was associated with keywords such as "family roles, father-mother responsibility, and parenthood," while the latter was linked to respondents' perceptions and ideals of "family." Each of the interviewees was assigned a pseudonym to sustain anonymity of data. To validate findings, the author referred to existing related literature.

\section{Overview of Filipino Migrants in Japan}

In line with distinguishing the group of Filipino migrant mothers on welfare, this section provides an overview of Filipino migrants in relation to the overall migrant population in Japan. Filipinos, along with Brazilians, Peruvians, and other Southeast Asian migrant groups comprise Japan's "newcomers" (Kondo 2008, p. 19; Komai 2001; Sellek 2001). The first wave of Filipino immigrants arrived in Japan in the 1970s (Burgess, 2008; Piquero-Ballescas, 1992). With 202,974, Filipinos are the fourth largest group of immigrant residents in Japan (Ministry of Justice, 2012).

Aside from colonial linkages, Filipinos have established vis-à-vis Japanese in several highly transnational ways. One pattern pertains to Japanese men who went on business venture in the Philippines and eventually established sexual and marital liaisons with Filipinas. As of 2010, there are about 11,583 Japanese living in the Philippines (National Statistics Office, 2010), which presumably indicates that some Japanese fathers opted to settle in the Philippines. Another pattern is through Filipinas who became hanayome (brides) to Japanese men via Japan-Philippine (local) government-mediated labor and marriage migration systems which helped curb declining populations in the rural villages.

These efforts of local governments in both countries were complimented by the growing number of matchmaking agencies which contributed to the formation of Japanese-Filipino inter-unions (Satake 2004; Suzuki 2003). (The more contemporary Japanese-Filipino marriages are formed between Japanese and entertainers or former talents how they call themselves) who have overstayed, a growing trend persisted following amendments on Immigration law in 1994 and 2005, respectively, which consequently tightened the entry of Filipino entertainment workers in Japan (Tutor 2006). As of 2012, there are 3,517 Japanese men-Filipino women marriages compared to only 139 Japanese women-Filipino men marriages registered in Japan. Not all these marriages succeeded.

In 2012 alone, out of the total 16,288 divorces, 3,811 Japanese men-Filipina women and 109 Japanese womenFilipino men marriages were dissolved (Ministry of Health, Labor and Welfare, 2012). The breakdown of Japanese-Filipino marriages increased the number of single mother households, which has become one of the major shifts in contemporary Japan's family structure. How are Filipino migrants coping with their current status in Japan?

In his recent talk, sociologist Naoto Higuchi (2011) of the University of Tokushima elaborated on the socio-economic problems migrants currently face in Japan. In his data, Filipino migrants have roughly $45 \%$ relief rate, the fourth largest group receiving public assistance (Higuchi 2011). Above $80 \%$ of Filipino migrant women in Japan are unmarried or single mothers who are actively participating in the labor force. Higuchi (2011) thus emphasized poverty as a source of Filipina migrants' vulnerability attributed to social structural problems which impedes their social integration to Japanese society.

\section{Results}

To verify Higuchi's account of Filipino migrants in need of welfare support, the next section aims to detail subjective experiences of respondents currently under the living subsidy program. It begins with identifying the profile of Filipino women on welfare, their perceptions on the living subsidy program, and finally, their views on the relationship between welfare consumption and family life in Japan.

\section{Who Are Filipino Mothers on Welfare in Japan?}

A. Melanie: a full-time wife of a Filipino and mother of three. 
Melanie is divorced from her Japanese husband of 2 years. She was offered permanent resident visa by her former husband in exchange for custody over their daughter. In 2000, she got married to a Filipino, Tony, who was then an undocumented migrant but was given a long-term visa in 2007 through Melanie's permanent visa status. As Tony was unemployed, Melanie had to continue working at the bar. Upon knowing her family's economic situation, Melanie's boss suggested inquiring at the welfare division of the nearby city hall for public assistance. At the city hall, the staff required Melanie to submit a record of tax contributions which were paid for by her ex-husband and became the main basis for passing the application for seikatsu hogo. For 11 years now, Melanie and Tony, with their brood of three, have been continuously receiving living allowance. Tony dabbles two part-time jobs, one of which is reported to the city hall in order to calculate subsidy adjustments. Melanie, meanwhile, has stopped working at the club since their second child was born, although she has planned to go back to work as soon as she finds a helper who will take care of her children, an agreement she made with Tony.

B. Queenie: a DV victim on custody battle.

Queenie came to Japan in 2001 as a talent (entertainer). At the bar, she met Ishii, who eventually became her husband. Their marriage started well but became abusive after their first child was born in 2005 . She filed for divorce in 2006, but financial setbacks prompted her to return to him. The relationship did not improve, however, and Queenie ran away again. Confused and traumatized, she sought the aid of an NGO who sheltered her and her son. A friend convinced her to file for seikatsu hogo. While her documents were complete, the city hall did not immediately confer her subsidy. From emptying her bank account (to prove she was financially in need) to feeding her baby with rice wash and dressing him with used baby clothes from the shelter, Queenie recalled the discipline she had to go through in order to qualify for seikatsu hogo: "The more I showed them that I have the means to rear my child, the more they would not give the allowance, so I had to prove to them that I am in dire need..." At the time of interview, she has been on seikatsu hogo for more than a year and has been residing in an apartment with her son. She prays to be reunited with her daughter who is with her ex-husband's family. After losing in the lower court, she still hopes her petition for child custody will be favored at the higher court. She desires to work again provided she gets a danchi (government-owned house), a slot at hoikuen (daycare), or a babysitter she can pay to take care of her kids.

C. Jessa: battered and mentally challenged.

Jessa came to Japan after her marriage to Nakayama whom she met in the Philippines through a friend. For years, she struggled with family life due to lack of familiarity with Japanese language and culture. Nakayama's unstable job forced her to work in order to augment the family's income, a decision which started frequent fights between them, which often involved verbal and physical abuse. Although she desired to keep the family intact, survival compelled her to escape with Mika. A Filipino friend housed them for a while. Having no knowledge of Japanese, Jessa's seikatsu hogo application was turned down a couple of times until a Japanese friend offered her assistance. Apart from mental depression as a result of physical abuse, Jessa recounted the trauma of being thoroughly screened as part of the subsidy application process:

The case worker thought that I was lying, that I was not really sick and just wanted to get benefits. So, I had to tell him that my husband got imprisoned for being involved in a brawl, which was true. I also had to prove to him that I was in need of medical help and worried so much for the fate of my daughter who witnessed how I suffered from her father's abuse. (Jessa, Interview, June $28,2011)$

Thus, proving her sincerity was crucial to the approval of Jessa's application for support. Even though she has been a seikatsu hogo beneficiary for 12 years now, Jessa would like to continue working even though she has yet to recover from mental depression. At the time of interview, Mika was 17 years old and has started a part-time job to partly support their family. Jessa is concerned about reporting Mika's work status to the city hall which we will reduce the amount they regularly receive. She wished for the government to be considerate of her health condition, their budget shortage, and her daughter's college education.

D. Linda: unmarried with dreams of a "whole" family.

Linda came to Japan as a talent in 1998. In her last year in Japan, she met Kanda who followed her to the Philippines and pledged for her education. In 2002, Linda was back in Japan with a student visa and enrolled in a vocational school where she studied Japanese. Her relationship to Kanda produced a son in 2003 and a daughter in 2006. Kanda helped her secure a permanent visa in 2005. Acquiring a permanent resident status, Linda holds, is a privilege for unmarried Filipinas like her. Since their breakup in 2008, Linda has asserted full responsibility over her two kids. She initially opted for boshi katei (living allowance for single mothers) since she is aware of the negative impressions most people have on seikatsu hogo), but the welfare staff offered her seikatsu hogo. At the time of interview, she has been receiving living subsidy allowance for more than a year. 
As a beneficiary, part of her duty is to inform the city hall of her financial status by reporting her monthly salary (from her part-time job as a cook) as well as Kanda's occasional paternal support. She expresses contentment in receiving seikatsu hogo, while balancing domestic duties and part-time job well. Linda aspires to marry someone who can be a father figure to her two children.

E. Delia: undivorced mother of two.

Delia was a house helper for years in the Philippines before coming to Japan in 2000 to become wife to Matsumoto, a friend of his former boss. It was marriage for convenience, Delia thought, since she never fell in love with him. The marriage was short-lived, and Delia got divorced without getting a permanent visa. Her second marriage was with Suzuki, which blessed her with two children and a permanent visa. A few years later, however, Suzuki's consequent problems at work severely affected his relationship with Delia and the kids. When he sent them out of the house, Delia turned to her friends for help. They sought the aid of an NGO who assisted Delia's divorce and seikatsu hogo papers. Like Jessa, Delia also had to go through what she described as a "painful" test of eligibility for living subsidy:

It was like a huge conference, but I would call it torture. Even the NGO worker who accompanied me trembled during interview. They kept on asking me to repeat my painful story, as if they were thrusting a dagger deep in my heart. Being on seikatsu hogo is no joke. You have to tell everything...the investigation was very thorough and I had to win their trust. But when I passed that, I felt relieved for myself and my children. (Delia, Interview, June 25, 2011)

Delia was granted seikatsu hogo on the primary condition that she must rear her two sons properly. In 2009, her husband died. Delia did not get divorced and was condemned by her in-laws. In spite of her traumatic experiences, Delia opted to remain strong for the sake of her children. During this interview, she has worked as a part-time lunchbox maker. She finds the living subsidy allowance sufficient for them, and she occasionally sends money to her family in the Philippines for contingency. Delia revealed that she has applied for a danchi. She plans to wait for her younger son to reach grade school before she works full time.

Based on the five narratives, descriptions on the profile of Filipino women on welfare can be drawn. In terms of civil status, Melanie is married to a Filipino, while the rest are either unmarried, divorced, or widow of their Japanese husband. In terms of entry to Japan, two are former entertainers, while the other three are mail-order brides. Most of them survived domestic violence and received information and assistance with regard to subsidy application from NGOs and a network of friends. In terms of legal status, four out of five are already permanent residents while one still holds a long-term visa. Except for one who has mental disability, the rest are determined to go back to work on the basis of desired family conditions. These demographic characteristics shaped their perceptions on welfare use which are discussed in the next subsection.

\section{How Do Filipino Migrant Mothers Perceive Seikatsu Hogo?}

The five mothers all agreed in viewing seikatsu hogo as a privilege for non-citizens of Japan. The rigorous screening processes and tests they underwent proved that seikatsu hogo is not a resource for all the needy. The means testing for seikatsu hogo, rather than a method to assess income and assets that should require individuals to "spend" their way into poverty in order to qualify (Myles (2002) as cited in Esping-Andersen Gosta 2000, p. 161), has become a tool that constrains Filipino migrant mothers' representation of poverty in order to fit the welfare authorities' normative idea of "being poor."

In Clarke's (2004, p. 33) words, immigrants must embody patterns of need that have been predetermined, pathologized, and legitimated by welfare authorities. Migrants' experiences in acquiring seikatsu hogo proved of the intrusiveness of the means test standards which is the root of stigmatization on the part of welfare recipients. However, these experiences are not distinct from Japanese citizens receiving seikatsu hogo. As Aoki and Aoki (2005, p. 14) as well as Iwata (2007, p. 44) proved, the prejudice against Japanese families on welfare are manifested in conversations with government support system employees, caseworkers and community professionals cultivate discriminating attitude toward welfare dependents in general.

Filipino migrant mothers in this study regard seikatsu hogo as a source of empowerment. For single mothers who were also victims of domestic violence, seikatsu hogo has liberated themselves from abusive relationships and renewed their notion of family (to be discussed further in the family relations section). While the family remains to be an important social ideology both in Japanese and Filipino societies, migrant mother recipients view that the family must not solely depend on a male breadwinner. Melanie's case shows that obtaining seikatsu hogo gives a wife a level of dominance over her husband, apart from getting a legal status through her permanent visa. Quite parallel to her stance is Linda's. Being unmarried gives her a sense of freedom and control over her family without a husband. 
Are Japanese mothers as empowered as Filipinos? Takahashi (as cited in Chan et. al. 2010, p. 54) pointed out that divorce and single parenthood are social risks in Japan which have resulted in conflicts and power imbalances in family relations. Japanese policymakers, she added, have refrained from conducting policy interventions claiming that divorce (or lack of it) and domestic violence are private matters that individuals involved should overcome on their own. As a result, the current generation of Japanese women has passively resisted social norms pertaining to women as sole child caretakers (Chan et. al., 2010, p. 51). In 2000, only $10.6 \%$ of lone Japanese mothers relied on seikatsu hogo, a ratio that has remained relatively low throughout the postwar period (Ezawa 2005, p. 52). The minimal percentage of Japanese women receiving seikatsu hogo implied that the subsidy has not been a primary source of support. Thus, it does not necessarily empower Japanese women socio-economically, compared to Filipino migrant women in this study.

Likewise, the researcher viewed Filipinas' notion of empowerment with skepticism. Filipino migrant mothers may have perceived seikatsu hogo as a benefit, not for being migrant individuals who are socially at risk, but as mothers who lack resources for child care. Therefore, it is possible to infer that Japan's welfare state has taken responsibility for the breakdown of families, and granting migrant mothers access to welfare subsidy has placed them under a "mother contract" to fulfill childcare responsibilities. Such circumstance reinforces Japanese welfare state's maternalist tendencies (Estevez-Abe 2008, p. 22), which promote women's subordination through welfare policies (Marfording 1997, p. 437), buttressing patriarchy and the "breadwinner model" by endowing Filipino migrant mothers as wives and mothers with living support rather than as social citizens in their own right (Pateman, 1989 cited in Crompton 2006, p. 15).

Social citizenship is a core concept of welfare state that must involve not only granting social rights but also, EspingAndersen Gosta (2000 p. 164) proposed, ensuring that individuals' position interlocks with the roles of the market and family. As Ann Shola Orloff $(1993,1996)$ pointed out, social citizenship, in relation to gender, should not only ensure protection from market and family failures by gaining access to basic welfare, but should also guarantee women's social and economic autonomy. Filipino migrant mothers may view themselves "empowered" with reference to overcoming hardships alluding to poverty, failed marriages, and broken homes by acquiring seikatsu hogo, but this does not necessarily warrant social citizenship which can be manifested through maintaining a household without relying on labor market or family support. Lister (1997; also cited in Brush 2002, p. 164) terms this "defamilialization," a process in which welfare regimes like seikatsu hogo endows women with "leverage against forces that downgrade care work, child bearing, household formation, and sexuality to normative femininity in the context of marriage."

Seikatsu hogo also shapes migrant mothers' consciousness on the existing socio-economic hierarchy among welfare recipients. According to them, seikatsu hogo beneficiaries tend to be at the bottom of hierarchical structure based on the fact that the living subsidy system covers all aspects of human survival (as mentioned in the introduction). Seikatsu hogo, among other welfare assistance programs, creates a stratification of vulnerable groups. The degree of vulnerability is quite ambiguous and challenging to measure in this group of migrant mothers herein because of the politics involved in their acquisition of seikatsu hogo. What is clear, however, is that migrant mothers are cognizant as well on the stigmatized and negative images of seikatsu hogo recipients, which initially hindered their application apart from social and cultural barriers (e.g., lack of knowledge in Japanese, discriminating images of Filipinos and single mothers, marginal views on poverty).

Melanie described seikatsu hogo as a "way of stealing citizens' taxes," while Queenie interpreted it as a "measure of poverty level" which placed seikatsu hogo recipients at the lowest rung of society. Delia, on the other hand, regarded recipients of boshi katei of a higher rank. She reasoned out: "If people know you are on seikatsu hogo, you are immediately looked down upon; but if you tell them that you are getting boshi katei, you have higher status because you only receive (an) allowance." All of them support that those migrant mothers living in danchi are in the best position among welfare beneficiaries for paying monthly amortization as their sole financial task and being able to work to support their family and obtaining jido teate (childcare allowance) which is only a minimal amount, compared to those on living subsidy program that meant dependence for survival. This justifies migrant mothers' aspiration of securing a danchi in order to be destigmatized.

Delia promised herself: "If they prioritize me to get a danchi, I will do my best to get out of here (seikatsu hogo). It is a pity to be on seikatsu hogo for a long time. I do not want to remain marginalized in the minds of the Japanese." Queenie confessed: "I often ask myself: is this the best thing I could be (being on seikatsu hogo)? Then, I try to convince myself that this support is temporary. I have to prove myself to them (the Japanese)." Migrants' discourse on seikatsu hogo thus characterizes welfare state as a system of stratification (EspingAndersen Gosta 2000 p. 165). In the case of migrant mothers, seikatsu hogo is a program that has generated social dualisms in the emergence of dual social stratifications that segregate (1) citizens and migrants as well as (2) migrants based on seikatsu hogo, boshi katei, and danchi benefits.

The first hierarchy designates citizens and migrants on seikatsu hogo below those who are not on welfare, are paying taxes, and are able to maintain high standards of living in 
Japan. The second layer further fragments the migrant group in terms of access to different kinds of welfare support. Hence, migrants on welfare constitute diverse groups and do not share the same socio-economic status. What can be gleaned from here is that migrants on seikatsu hogo occupy the base of both stratification systems. This provides one of best explanations as to why most migrant mothers in this study are highly driven to work again in order to regain social inclusion.

In his discussion of the politics of social inclusion and exclusion, Halfmann (1998, p. 516) argued that inclusion is an indicator of social citizenship which provides individuals with career choices and bestows upon individuals the right to access and mobilize resources. In line with the first hierarchy, migrants envision to achieve integration to Japanese society. The second hierarchy might be more difficult to overcome since migrants differ in terms of mode of migration, legal status, occupation, education, and other indicators. An important point to be stressed here is that seikatsu hogo, along with other welfare services, is a constructor of hierarchies that further diversify and stratify migrants receiving them.

In summary, Filipino migrant mothers perceive seikatsu hogo as a privilege limited to a certain group of vulnerable migrants. Whereas it is perceived to be an empowering resource, further analysis reveals that it underpins a male "breadwinner model" of a family and maternal childcare. Finally, seikatsu hogo affirms the prevailing hierarchies in Japanese society characterized by two levels of poverty, one that fragments Japanese upper and middle classes and Japanese "poor" and the migrant "poor", and the other exists among migrants on different welfare benefit systems. Locating migrants on seikatsu hogo at the lowest segment of the two strata commits migrant mothers to rejoin the workforce with considerations that are primarily dependent on their family. This salient point leads to the next section, which discusses how Filipino migrant mothers politicize family relations in cognizant to seikatsu hogo consumption.

\section{How Are Migrant Mothers' Views on Family Relations Linked to Their Perceptions?}

Elucidating migrant mothers' politics of family relations entails two useful conceptual tools, the concept of family obligation and family solidarity. These theoretical constructs specify the key issues in family relations that are reconfigured through seikatsu hogo use.

Filipino migrant mothers articulate family obligations with reference to the breakdown of marriage. Coming from the Philippines, a nation state where there is no divorce, they see Japan as a state that liberates women from an unhappy married life. Such perception, oftentimes, causes them to view marriage as a weak institution, incapable of strengthening the family structure. However, rather than blaming the presence of divorce law or the lack of sufficient welfare services to keep the family intact in Japan, Filipino migrant mothers, particularly those single mothers, attributed marital breakdown to themselves. Despite marital failure, a number of women in this study have not lost faith in the family, though the way they defined has been reconstructed. Incorporated into their notion of a family is intensified commitment to parent-child relationships that are not solely based on blood/kinship ties.

Furthermore, Filipino mothers perceive seikatsu hogo as a social safety net that replaces failed marriage and enables them to regain some degree of self-sufficiency. It is important to stress here, however, that Filipino women do not necessarily utilize marriage simply to gain socio-economic mobility, ${ }^{2}$ which cannot be a general feature of Japanese-Filipino marriages (cf. Satake 2004). Japanese men who marry Filipino women do not always have high socio-economic capital to guarantee the improvement of their wives' status. This could be seen in the cases of Jessa and Delia who were previously married to Japanese men, but assumed the role of a breadwinner almost throughout the marriage. Nonetheless, as Jenson (2009, p. 472) argues, the welfare state has "substituted for the breadwinner" so as to guarantee minimum income to mothers as well as their children through family allowances, seikatsu hogo subsidies in this paper.

One of the stigmas attached to seikatsu hogo is the truth referring to migrant recipients as mostly single mothers who failed as wives. However, this stigma is overshadowed by Filipino women by performing childcare responsibilities. It is not surprising that those single migrant mothers who "lost" their husbands retained motherhood since having custody rights over children warrants seikatsu hogo, among other benefits. Jessa put it best: "Failure as a wife is less degrading than failure as a mother. I felt rewarded when my daughter chose me over her father. To me, that is all that matters." These views affirmed Daly's (2006, p. 137) argument that parental obligations outlast marital breakup. When families are led by unmarried women, as in the case of Linda, paternal absenteeism does not hinder commitment to raising children.

Despite having a spouse, some married women like Melanie likewise prioritize childcare which is a major concern prior to returning to work. The fulfillment of maternal roles is one of the primary expectations on them by the welfare authorities. Hence, attending to children's needs and sustaining "quality parenthood" are fundamental to disciplining migrant mothers. Clarke (2004, p. 33) affirmed that social policies are often shaped to police, reform, and direct the culture of its migrant beneficiaries. To maintain welfare support, migrant mothers must foster "good parenthood." Linked to

\footnotetext{
${ }^{2}$ Constable and her group's compilation of cross-border marriages in Asia undermines global hypergamy, the notion that women utilize marriage mainly as a tool for social mobility. See Constable, N. (Ed.). (2011). Cross-border marriages: Gender and mobility in transnational Asia. University of Pennsylvania Press.
} 
this idea of seikatsu hogo as a mechanism for disciplining migrants are structural laws that prohibit accumulation of savings for children's education (Aoki and Aoki 2005, p. 11), full-time work especially at night, sending remittances, and going back to one's country. Such provisions are problematic and have caused massive incidence of deviance, confessed by some respondents in this study.

Moreover, the notion of discipline imposed by seikatsu hogo onto the lives of migrants can be observed in their strong identification of themselves as responsible parents who, different from the "deviants," have no vices, consume secondhand goods and appliances, improve knowledge of Japanese language, participate in community building, and religious communication with the welfare authorities. Dutiful reporting is an indicator a disciplined welfare recipient, which entails informing one's caseworker of the children's progress at school, their health, among others. Indeed, these realities validate Daly's (2004, p. 138) claim that the welfare state has increasingly been intervening in the roles and responsibility of the family. Also evidently, the welfare state's power to intervene has reduced the public-private boundaries (Fraser 1997, p. 62).

Filipino migrant mothers' standpoints on family solidarity have broadened their grasp on family relations in the context of utilizing seikatsu hogo. The first indicator of family solidarity is the concept of "best mother" who is able to harmonize work and motherhood (Esping-Andersen Gosta 2000; also in Jenson 2009, p. 465). Basically, migrant mothers are all convinced that motherhood requires balancing maternity and employment, although most of them are hindered from becoming active in labor force due to parenting duties, problematized earlier by their reinterpretation of their role as a "good parent" above all. Migrant mothers are aware of the necessity of work as a determinant of their life progress, as much as this leads to gradual removal from seikatsu hogo, and ultimately to their social inclusion. With these aspirations in mind, they have drawn a time frame for regulating their family obligations in order to be active in the labor force.

Prerequisite to fulfilling these goals, most mothers in this study are currently awaiting their danchi and hoikuen applications that will allow them to engage in work again without sacrificing parenthood. Some of them, as the cases of Melanie and Queenie, have expressed willingness to pay a private babysitter who can take care of their children while they are at work. Linda, on the other hand, juggles two part-time jobs but strives to devote "quality time" for her two children. This variety of life course decisions that mothers make in relation to their children espoused the notion of choice. Hakim (2003: as cited in Crompton 2006, p. 11) emphasizes that mothers' practice of making choices depict their diverse employment patterns. She notes that mothers who tend to prioritize their maternity often resort to part-time work. What divides these migrant mothers' time-framing and decision-making practices with regard to work and maternity is, they construed, the age of their children. Having a 1-year old kid, Queenie finds herself disadvantaged since welfare authorities bind her completely down to mother duties. Her situation exposes Crompton's point (2006, p.13) that although mothers can have "choices," they fulfill it so within the "normative (moral) framework" instituted by the welfare state. Thus, those mothers who succeed in balancing family and work have better status and greater control over their welfare. Furthermore, regulated choice-making on the part of migrant mothers reveals their lack of political influence.

Like other new social risk (NSR) groups, Bonoli (2006) pp. 392-393) identified migrants in general as those groups at social risk who lack political participation and representation. These limitations are evident in migrants' lack of solid political base and substantial power resource that might be useful for advancing welfare policy reforms in Japan. When asked whether they would seek reform, they unanimously expressed contentment over the status quo, which echoes their lack of political commitment to transform seikatsu hogo.

Overlapping with the "best mother" idea is the concept of "model adult citizen" which likewise surfaced in migrant mothers' views on family solidarity. As Lister (2006, p. 174) explicated, a "model adult citizen" should possess independence by integrating herself into the labor market instead of depending on the state. As mentioned earlier, migrant mothers have expressed mainly gratitude for their access to benefits, and they do not seek welfare reforms. Mother respondents engage the politics of economics exchange by upholding the Filipino cultural ideal of "utang na loob" (debt of gratitude) and the Japanese ideals of "kimochi" (good feeling) and "ganbaru" (doing one's best) for the sake of the family. They, repaying the "generosity" of the welfare state, can be achieved through leading a decent life with simple lifestyle and obtaining social capital (Daly 2004, p. 145) by acquiring Japanese communication skills for their children and society, doing community services, performing maternal functions, and, above all, work.

Migrant mothers reasoned out that the state cannot be blamed for the insufficiency of seikatsu hogo. Therefore, reforms which call for its expansion would indirectly imply, in their view, ingratitude. As elucidated by Iwata (2007, p. 29), most welfare recipients attribute their failure and success in life to their own life decisions and actions rather than blaming it on social structures. Instead, as model citizens, migrant mothers should do their part in the exchange by working hard in order to substantiate seikatsu hogo. The idea of modeling, linked to seikatsu hogo is, therefore, equated with labor participation to reduce welfare burdens. These arguments clearly show the prevalence of individualism as a feature of a "model adult citizen." Giddens (1991: 75, also in Crompton 2006: 9) said it succinctly: "We are what we make of ourselves." In 
the context of "model adult citizen," how we envision becoming a role model to our children relies on how we engage in various endeavors.

Long-term dependence on seikatsu hogo is deemed unworthy of becoming a model for the Japanese society and family. To become a worker, like the Japanese, is a manifestation of love for one's family (Retherford et al. 2001, p. 91). While migrant mothers value employment, they do not completely exchange motherhood for it. Rather, they desire reconfiguring family arrangements by seeking other sources of welfare assistance (e.g., danchi, hoikuen) to temporarily entrust their children to others in order to generate socio-economic capital. It might be quite dismal to determine how and when migrant mothers could actually succeed in altering the kind of welfare they access, but what seems clear is they renounced reliance on seikatsu hogo as temporary. To achieve autonomy with and for the family and to be able to raise one's standards of living means overcoming dependence from seikatsu hogo and ultimately to all the stigmas the society has attached to welfare consumption.

This section has discussed the politics of family relations in tandem with seikatsu hogo utilization, using family obligations and family solidarity as the main analytical tools. Family relations have been a dynamic site for evaluating the meaning and impact of seikatsu hogo in the lives of Filipino migrant mothers and their families in Japan. Family obligations were redefined by migrant mothers upon reflecting on their marital failures and the effect of divorce as the state's legal device for sanctioning dysfunctional relationships. Embracing the idea that families need not be fathered, Filipino migrant mothers give credence to their parenting abilities with the support of seikatsu hogo as the "substitute breadwinner." Parenthood largely depicted herein as motherhood over marriage bolsters seikatsu hogo as primarily a family support. Seikatsu hogo is the mechanism of the welfare state to discipline and direct the lives of its migrant dependents. It legitimizes the power of the state to redistribute roles and expectations in the family and minimize the private-public divide.

Family solidarity can be drawn from Filipinas' visions of becoming the "best mother" and "model adult citizen." Filipino mother respondents hold that they can advance being the "best mother" by striking a balance between paid and unpaid work. Migrant mothers' practice of choice-making is hampered by their lack of political resource that disinterests them from articulating welfare reform that may benefit them and their families. The "model adult citizen" idea denotes revaluing labor force participation to reclaim control over life and future. This concept is evident in the way Filipino migrant mothers perceive reintegrating to the workforce implies temporarily defamilializing oneself through delegating childcare tasks to other social institutions to eventually be refamilialized by reclaiming control over oneself and the family. Hence, migrant mothers who can become "model adult citizens" will no longer be at the bottom of socio-economic hierarchies, and rather than being "magnetized" by the welfare state's "generosity," they prefer being de-stigmatized from welfare use.

\section{Conclusion}

This paper identified Filipino migrants who are currently on welfare in Japan, established the relationship between their politics of welfare consumption and family relations, and analyzed the impact of welfare on their reconstructed notions of family.

As illustrated, the living subsidy allowance has become an instrument of the welfare state to promote the ideology of familialism which delegates childcare to women. While Filipino migrant women view this benefit as the state's act of "generosity" to inspire their renewed commitment to parenthood, they are cognizant of their equal importance of labor force participation as the key toward their integration to Japanese society, a vision they share with Japanese women. In 2011 , it was reported that $38 \%$ of the total $2,237,000$ working Japanese women continued their career after giving birth and projected to go as high as $50 \%$ by 2015 (Ministry of Health, Labor and Welfare 2012). Hence, in grappling with graying population and complex labor market problems, Japan must reconsider maximizing women's potential and human capital, both Japanese and non-Japanese, by widening their economic visibility. In order to do so, the government must expand childcare facilities and health care benefits to ensure women's and families' well-being in general. To be fair, the government is on its way to develop stronger support systems toward work and family life balance (Ministry of Health, Labor and Welfare 2012).

Another crucial challenge to the future of Japan's welfare system alludes to whether it should be universal or particularistic in terms of welfare policies and provision for social rights to its immigrant residents. Should Japan choose to be universal, it must work toward making welfare benefits available beyond the needy in order to eliminate stigmatization that tends to disorient citizens and non-citizens on the real functions of welfare state. If it chooses to be more particularistic, it should judiciously do so within the context of a multicultural society, thus recognizing specific social needs of immigrants by improving existing welfare systems, making information on social welfare services more accessible to immigrants.

This paper is an attempt to uncover the truths about these labeled vulnerable groups. Homogenizing the fate of migrants as welfare recipients perpetuates the continuing invisibility of their dislocations and of the varying discourses on welfare use from the perspective of its consumers. This research, taking a more gendered and familybased approach to the study of immigrants on welfare, can be utilized for cross-comparison with other migrant women 
and can also be used to examine the experiences of other immigrant groups in Japan to accommodate more nuanced perspectives on immigrants' culture of welfare consumption.

\section{References}

Adolino, J., \& Blake, C. (2001). Comparing public policies: issues and choices in six industrialized countries. USA: CQ Press.

Aoki, O., \& Aoki, D. M. D. (2005). Invisible poverty in Japan: case studies and realities of single mothers. Journal of Poverty, 9(1), 1-21.

Aspalter, C. (Ed.). (2002). Discovering the welfare state in East Asia. Greenwood Publishing Group.

Blumer, H. (1969). Symbolic interactionism. Englewood Cliffs: Prentice Hall.

Bonoli, G. (2006). The politics of the new social policies: providing coverage against new social risks in mature welfare states. In C. Pierson \& F. G. Castles (Eds.), The welfare state reader. Second Ed: Polity Press.

Brush, L. (2002). Changing the subject: gender and welfare regime studies. Social Politics, 9(2), 161-186.

Chan, Raymond K. H, Takahashi, Mutsuko and Wang Lillian Lih-Rong. (2010). Risk and Public Policy in East Asia. Burlington: Ashgate Publishing Limited.

Clarke, J. (2004). Changing welfare, changing states. London: Sage.

Crompton, R. (2006). Understanding change in employment, family, and gender relations in employment and the family: the reconfiguration of work and family life in contemporary societies. Cambridge University: Press.

Daly, M. (2004). Changing conceptions of family and gender relations in European welfare states and the third way. Welfare state change. Towards a third way, pp.135-154.

Esping-Andersen Gosta. (2000). "Three Worlds of Welfare Capitalism" in Pierson, Christopher and Francis Castles (Eds.), The welfare state: a reader. Cambridge: Polity Press. pp. 160-174.

Estevez-Abe, M. (2008). Welfare and capitalism in postwar Japan. Cambridge: Cambridge University Press.

Estevez-Abe, M. (2009). Gender, inequality, and capitalism: The "varieties of capitalism" and women. Social Politics: International Studies in Gender, State \& Society, 16(2), 182-191.

Ezawa, A. (2005). Lone mothers and welfare-to-work policies in Japan and the United States: towards an alternative perspective. Journal of Sociology and Social Welfare, 31(4), 41-63.

Fraser, N. (1997). After the family wage: a postindustrial thought experiment. Justice Interruptus. London: Routledge

Hakim, C. (2003). Models of the family in modern societies: Ideals and realities. Ashgate.

Halfmann, J. (1998). Citizenship universalism, migration and the risks of exclusion. The British Journal of Sociology, 49(4), 513-533.

Higuchi, N. (2011). The poverty of migrants and their children. A Talk delivered on April, 8, 2011.

Iwata, M. (2007). Identifying the poor: analysis of impoverished singlemother households. Journal of Poverty, 11(3), 29-45.

Japanese law translation. (2009). Retrieved from http://www. japaneselawtranslation.go.jp/law/detail/?id $=24 \& v m=04 \&$ re $=01$
Jenson, J. (2009). Lost in translation: the social investment perspective and gender equality. Social Politics: International Studies in Gender, State and Society, 16(4), 446-483.

Kamiya, S. (5 July 2011). "Sign of economic, aging times". Retrieved from http://search.japantimes.co.jp/cgi-bin/nn20110705i1.html.

Komai, H. (2001). Foreign migrants in contemporary Japan. Trans Pacific Press

Kondo, A. (2008). "New challenges for managing immigration in Japan in comparison with western countries" in migration and globalization comparing immigration policy in developed countries. Tokyo: Akashi Shoten.

Lister, R. (2004). Welfare state change: toward a third way? London: Oxford University Press. The Third Way's Social Investment State", in Jane Lewis and Rebecca Surender, Eds.

Marfording, A. (1997). Cultural relativism and the construction of culture: an examination of Japan. Human Rights Quarterly, 431-448.

Myles, J. (2002D). A new social contract for the elderly? In A. Gosta Esping (Ed.), Why we need a new welfare state. London: Oxford University Press.

Orloff, A. (1993). Gender and the social rights of citizenship: the comparative analysis of gender relations and welfare states. American Sociological Review, 58, 303-328.

Orloff, A. (1996). Gender in the welfare state. Annual Review of Sociology, 22, 51-78.

Pateman, C. (1989). The disorder of women: Democracy, feminism, and political theory. Stanford University Press.

Peng, I. (2002). Gender and welfare state restructuring in Japan. In C. Aspalter (Ed.), Discovering the welfare state in East Asia. London: Praeger. Greenwood Publishing Group.

Public assistance system. (n.d.). Retrieved from http://www.mhlw.go.jp/ english/topics/social welfare/dl/outline of the public assistance system_20101004.pdf

Retherford, R., et al. (2001). Late marriage and less marriage in Japan. Population and Development Review, 27(1), 65-102.

Satake, M. (2004). Filipina-Japanese intermarriages: a pathway to new gender cross-cultural relations. Asian and Pacific Migration Journal, 13(4), 445-473.

Sellek, Y. (2001). Migrant labour in Japan. New York: Palgrave Macmillan.

Soeda, Y. (1990). The development of the public assistance system in Japan, 1966-73. Annals of the Institute of Social Science, Special Issue on the Japanese Welfare State, 32, 1-35.

Solidarity network with migrants Japan. n.d. Retrieved from http://www. migrants.jp/v1/English/English.html

Suzuki, N. (2003). Transgressing 'victims': reading narratives of 'Filipina brides' in Japan. Critical Asian Studies, 35(3), 399-420.

Takahashi, M. (2010). Risk, family, and gender justice in contemporary Japan. In C. Raymond (Ed.), Risk and public policy in Asia. USA: Ashgate Publishing Company.

Tsuda, T. (2006). Localities and the struggle for immigrant rights: the significance of local citizenship in recent countries of immigration. In T. Tsuda (Ed.), Local citizenship in recent countries of immigration (pp. 3-36). USA: Lexington Books.

Tutor, B. (2006). "Undocumented Filipinos cross the great divide in Japan”. Retrieved from http://www.philippinestoday.net/index. php? module $=$ article \&view $=132$

Wright, C. (2001). "Unmarried single mothers in Japan: three suggested typologies”. Kyoto Koka Women's University Journal, 39, 67-99. 